\title{
1 Population size of Oystercatchers Haematopus ostralegus wintering in
}

2 Iceland

3

Böđvar Pórisson ${ }^{1 *}$, Verónica Méndez ${ }^{2,1}$, José Alves ${ }^{1,3}$, Jennifer A. Gill², Kristinn H. Skarphéđinsson ${ }^{4}$, Svenja Auhauge ${ }^{4}$, Sölvi R. Vignisson ${ }^{5}$, Guðmundur Ö. Benediktsson ${ }^{6}$, Brynjúlfur Brynjólfsson 7 , Cristian Gallo ${ }^{8}$, Hafdís Sturlaugsdóttir ${ }^{8}$, Páll Leifsson ${ }^{9}$ \& Tómas G. Gunnarsson ${ }^{1}$

8

${ }^{1}$ University of Iceland, South Iceland Research Centre, Lindarbraut 4, IS-840 Laugarvatn, 10 Iceland

${ }^{2}$ School of Biological Sciences, University of East Anglia, Norwich Research Park, Norwich NR4 7TJ, UK

${ }^{3}$ DBIO \& CESAM - Center for Environmental and Marine Studies, University of Aveiro, Campus Universitário de Santiago, 3810-193 Aveiro, Portugal

${ }^{4}$ Icelandic Institute of Natural History (IINH), Urriðaholtsstræti 6-8, 212 Garðabær, Iceland

${ }^{5}$ Sudurnes Science and Learning Center, Garđvegur 1, 245 Sandgerđi, Iceland

${ }^{6}$ Duggugerđi 1, 670 Kópasker

${ }^{7}$ South East Iceland Bird Observatory, Litlubrú 2, 780 Höfn, Iceland

${ }^{8}$ Westfjords Natural History Institute, Ađalstræti 21, 450 Bolungarvík

${ }^{9}$ Strandgata 7a, 735 Eskifirði, Iceland

$21 *$ Corresponding author bodvar@hi.is 
1 Capsule Iceland-breeding Oystercatchers winter in both Iceland and W Europe, but the 2 relative numbers of residents and migrants is poorly known. We undertook the first ever 3 survey of the total number of Oystercatchers wintering in Iceland. Around 11,000 individuals 4 were counted which almost triples the previous estimate. This is an estimated $30 \%$ of the 5 Icelandic population, including juveniles, suggesting that $\sim 26,000$ Icelandic Oystercatchers 6 migrate to W Europe in the autumn. More Oystercatchers winter in Iceland than at similar 7 latitudes elsewhere in Europe, which may reflect the remoteness and slightly milder winter 8 temperatures on this oceanic island.

9 


\section{Introduction}

Many species of birds are so-called partial migrants, where a part of the population is sedentary, remaining on or near the breeding grounds year-round, while another part of the population migrates (Alerstam 1990). Partially migrant populations are model systems for studying environmental drivers of variation in individual migration strategies and the consequences of those strategies for demography and evolution of migration (Hegemann et al. 2015). Partial migration at northern latitudes can involve trade-offs between survival of residents under harsh winter conditions and potential benefits for productivity driven by factors such as timing of territory acquisition and mate-retention probabilities (Durell 2007, Duriez et al. 2012). These trade-offs may be a key reason why individuals in populations which breed over large latitudinal ranges are often migratory at higher latitudes but sedentary at lower latitudes (Newton 2010). Migration can also incur costs related to migration distance and conditions at destinations (Alves et al. 2013, Lok et al. 2015). In order to use the structure of partial migrant systems to understand the demographic causes and consequences of migration, detailed information is needed about the migratory status of individuals across populations and the proportion of migrants and residents. For many large birds this can be achieved through direct observations or, for smaller birds, more often by indirect evidence of migratory status (such as differences in stable isotope ratios) (Palacín et al. 2011, Hegemann et al. 2015).

The Icelandic breeding Oystercatcher (Haematopus ostralegus) population is partially migrant, with the majority of individuals thought to migrate to coastal Europe during the winter (Garđarsson 1975). A recent estimate of the size of the breeding population is $\sim 13$ thousand pairs (Skarphéđinsson et al. 2016). No targeted survey of their total wintering 
1 number has taken place so the size of the sedentary Oystercatcher population in Iceland is

2 currently unknown. However, as Iceland lies at the northernmost latitudes of the winter

3 range of this species (BirdLife International 2017), the proportion of migrant individuals is

4 predicted to be high. The maximum wintering number counted in Christmas counts

5 organised by the Icelandic Institute of Natural History (IINH) since 1952 has been 4466

6 individuals (IINH 2017). Most Oystercatchers winter in SW and W Iceland but some are also

7 known to winter in unknown numbers in areas not covered by the Christmas counts. As part

8 of a larger project comparing demographic parameters of migrant and resident

9 Oystercatchers, we undertook the first total and targeted census of the Icelandic

10 Oystercatcher wintering population to estimate the proportions of migrants and residents in

11 this partial migratory population. We compare our results with the resident proportions of

12 breeding Oystercatcher populations across coastal NW Europe, between Norway and the

13 Netherlands, to assess the latitudinal gradient in migration behaviour of the species. Iceland

14 is a remote oceanic island with a sea crossing that is potentially more risky than migration in

15 other parts of the range, which may affect the partial migratory continuum (Gunnarsson \&

16 Tómasson 2011). 
Methods

Ground-based surveys of Oystercatchers were carried out between 28 January - 3 February 2017 and an aerial survey over the islands and inaccessible sites in the Breiðafjörður bay (Figure 1) was conducted on 16 February 2017. At this time, migratory Oystercatchers are unlikely to be present as colour-ringed migratory individuals do not start arriving in Iceland until March (unpublished data). Southwest and West Iceland are known to be the key wintering regions (Wilson \& Morrison 1981) as they have most of the suitable wintering habitats (estuarine bays) for Oystercatchers (Ingólfsson 2006) and a relatively mild winter climate (Icelandic Met Office; www.vedur.is). All potential and known wintering sites from Reykjanes peninsula in the SW, in Faxaflói and the north side of the Snæfellsnes peninsula in the W, along with key areas in the NW were surveyed on foot or by car (Figure 1). Christmas counts cover several coastal areas in the North and Oystercatchers are rarely found in this part of the country in the winter (IINH 2017). Only one area, Kópasker, was covered during our survey and produced no Oystercatchers. All known or potential wintering areas in the $E$ and SE were covered on the ground. Most of the south coast of Iceland comprises barren, sandy outwash plains of glacial origin which are unsuitable for wintering waders (Gunnarsson 2009) and was therefore not covered. Sites were surveyed with binoculars and telescopes, either on low or high tide, depending on the highly variable local conditions, to maximise the visibility of birds. An aerial survey over islands and inaccessible sites in the Breiđafjörđur bay, as well as some key sites in Faxaflói Bay, was conducted around high tides (+/- 2 hrs). We used a fixed-wing aircraft (Cessna-Skyhawk) flying at 120-200 m a.s.l. with a groundspeed of $120 \mathrm{~km} /$ hour. Flocks of roosting Oystercatchers were usually seen from afar and photographs were used to verify or correct counts without flushing the birds. During 
1 both ground and aerial surveys, all other waders which were encountered were also

2 counted. This information is not used in this study but is included in an appendix.

3 In order to estimate the proportion of migrants and residents it was necessary to determine

4 the total population size of Icelandic breeding Oystercatchers, which has recently been estimated at 13 thousand breeding pairs (Skarphéðinsson et al. 2016). Our studies during the past three years have shown that oystercatchers breeding both in inland and coastal habitats fledge on average $\sim 0.5$ chicks/pair (Méndez et al. unpublished). We estimate that $50 \%$ of these are alive by mid-winter (when the survey took place), that annual survival probability is $90 \%$ (Goss-Custard et al. 1982, Durell 2007) and that Oystercatchers start breeding at the age of 4 years (Ens \& Underhill 2014). These values were used to estimate the number of birds in the four juvenile cohorts, which were then added to the number of breeding adults to produce a total population estimate of both adults and juveniles in winter (estimated total winter population $=26,000$ adults + the estimated number of juveniles in each of the four juvenile cohorts (ages 1 to 4 )).

To put the migratory status of the Icelandic Oystercatcher into context with Oystercatcher populations breeding in NW Europe, we collated available information about the prevalence of residency in wintering of Oystercatchers in coastal countries along the East Atlantic flyway, north of France (see references in table 2). Average January temperature was extracted, as a surrogate for winter severity, from weather stations (https://www.yr.no) close to main wintering sites for each country. In areas with little or no wintering, weather stations closest to the centre latitude of the region were used. 


\section{Results}

2 In total, 11,141 Oystercatchers were counted in our survey (Table 1) which approximately

3 triples previous annual winter counts (Figure 2). As expected from previous studies, the vast

$4 \quad$ majority of Oystercatchers were found on wintering sites in SW and W Iceland. Large

5 numbers of Oystercatchers were found on sites not covered by the Christmas counts,

6 particularly on the north side of the Faxaflói bay and during the aerial survey over the

7 Breiðafjörður bay.

Assuming that our productivity estimate (see methods) applies across the population and assumptions about survival are reasonable, the four juvenile cohorts would total 11,177 juvenile birds in mid-winter. Adding that to the breeding population estimates gives a total mid-winter population of $\sim 37,177$ individuals. Our winter census results therefore suggest that $\sim 30 \%$ of the total population of Oystercatchers are residents, whereas the remaining $\sim 70 \%$ or $\sim 26,000$ Oystercatchers migrate out of Iceland to winter in W Europe.

Across the breeding latitudes of Oystercatchers in NW Europe, there is a strong latitudinal decline in residency which reflects the latitudinal trend in winter temperatures (Table 2). From Northern Norway $\left(69.6^{\circ} \mathrm{N}\right)$ to Southern Sweden $\left(57.7^{\circ} \mathrm{N}\right)$, where mean January temperatures are typically in the range of -1 to $-4^{\circ} \mathrm{C}$, only occasional individuals are found in winter, whereas populations in Denmark $\left(55.4^{\circ} \mathrm{N}\right)$, where mean January temperatures are $\sim 0.8^{\circ} \mathrm{C}$, and sites that are further south and warmer mostly comprise resident individuals (Table 2). 


\section{Discussion}

2 In the first targeted and complete survey of the wintering Icelandic Oystercatcher population we recorded $\sim 11,000$ individuals in Iceland, almost tripling previous annual winter counts.

We estimate that this represents $\sim 30 \%$ of the entire Icelandic population, including juveniles. There is currently no evidence that Oystercatchers from other breeding populations occur in Iceland (Skarphéðinsson et al. 2016). Wintering Oystercatchers occur primarily in the Southwest and West of the country, which has abundant estuarine feeding habitats and a mild winter climate. At present it is not known to what extent the wintering population comprises local breeders or how many originate from other parts of Iceland. Parts of Iceland which were not covered by the survey, particularly the North and East coasts have many areas which are surveyed during the Christmas counts and usually have few to no wintering Oystercatchers (IINH 2017). Areas which were surveyed both during the Christmas counts and during our census, approximately one month later, had very similar numbers of Oystercatchers, therefore any major redistribution during this time of winter is unlikely to have taken place but such events could increase the chances of double counting. We therefore conclude that our survey results should be considered a minimum estimate of the number of Oystercatchers wintering in Iceland. The information gathered here forms vital background for the assessment of the role of partial migration in the dynamics of this population.

There is a strong temperature-related latitudinal pattern in the proportion of wintering Oystercatchers from breeding populations across NW Europe. Towards the north, from Norway to South Sweden where mid-winter temperatures are generally below zero, virtually all Oystercatchers migrate. In the warmer winter regions above the $0^{\circ} \mathrm{C}$ isotherm, from 
1 Denmark to the Netherlands, most Oystercatchers are residents. This follows the general

2 pattern of birds being more likely to migrate from colder areas with declining food supplies

3 in winter (Newton \& Dale 1996, Newton 2010). However, there are two obvious outliers in

4 this pattern: Iceland has more wintering Oystercatchers than would be predicted by latitude

5 and the Faroe Islands have fewer residents (almost none) than would be predicted by the relatively warm winter temperature. Iceland might hold a higher proportion of residents as it is far enough away from Britain (about $750 \mathrm{~km}$ to mainland Scotland) and Ireland for the seacrossing to be a significant barrier, which may require considerable adaptation and preparation to cross (Gunnarsson \& Tómasson 2011, Alves et al. 2012). In addition, some coastal areas, particularly in the west of Iceland, provide relatively mild oceanic climate and apparently ample food stocks to support high survival during most winters. For another resident mussel feeder, the Common eider Somateria mollissima, analyses of long-term datasets spanning over one hundred years show that adult mass mortality due to inclement weather happens only occasionally (Jónsson et al. 2009, Jónsson et al. 2013). Conversely, the Faroe Islands have less feeding habitat available (Bengtson \& Bloch 1983) but even milder wintering conditions (Table 2). However, these islands are considerably closer to Britain (320 $\mathrm{km}$ to mainland Scotland) and Ireland than Iceland, and the risks associated with this shorter sea-crossing may thus be lower.

Our targeted surveys of the Icelandic wintering population of Oystercatchers showed that the population is much larger than previously estimated. Contrary to other wintering locations in coastal W Europe the proportion of residents in Iceland is high, which may relate to the remoteness of Iceland and the relatively mild weather conditions for this latitude. These results provide an insight into factors regulating partial migration at higher latitudes and an invaluable platform into further studies of this population. 
2 The study was funded by the Icelandic Research Fund grant no. 152470-052 and NERC grant

3 no. NE/M012549/1. Observers: Gunnar P. Hallgrímsson, Hallgrímur Gunnarsson, Jón

4 Jónsson, Margrét Thorsteinsson, Matthías S. Lýðsson, Petrína F. Sigurðardóttir, Sigurjón

5 Stefánsson, Sindri Gíslason and Yann Kolbeinsson.

6 


\section{References}

Alerstam, T. 1990. Bird migration. University Press, Cambridge.

Alves, J. A., Gunnarsson, T. G., Hayhow, D. B., Appleton, G. F., Potts, P. M., Sutherland, W. J. \& Gill, J. A. 2013. Costs, benefits, and fitness consequences of different migratory strategies. Ecology 94: 11-17.

Alves, J. A., Gunnarsson, T. G., Potts, P. M., Gelinaud, G., Sutherland, W. J. \& Gill, J. A. 2012. Overtaking on migration: does longer distance migration always incur a penalty? Oikos 121: 464-470.

Bakken, V., Runde, O. J., Tjørve, E. \& Koblik, E. A. 2003. Norsk ringmerkingatlas - Norwegian bird ringing atlas. Stavanger Museum, Stavanger.

Bengtson, S.-A. \& Bloch, D. 1983. Island Land Bird Population Densities in Relation to Island Size and Habitat Quality on the Faroe Islands. Oikos 41: 507-522.

BirdLife International. 2017. Species factsheet: Haematopus ostralegus [Online]. Available: http://www.birdlife.org [Accessed 3.10.2017].

Durell, S. E. A. L. V. d. 2007. Differential survival in adult Eurasian oystercatchers Haematopus ostralegus. J. Avian Biol. 38: 530-535.

Duriez, O., Ens, B. J., Choquet, R., Pradel, R. \& Klaassen, M. 2012. Comparing the seasonal survival of resident and migratory oystercatchers: carry-over effects of habitat quality and weather conditions. Oikos 121: 862-873.

Ens, B. J. \& Underhill, L. G. 2014. Synthesis of oystercatcher conservation assessments: general lessons and recommendations. International Wader Studies 20: 5-22.

Garðarsson, A. 1975. Votlendi. Landvernd, Reykjavík.

Goss-Custard, J. D., Le V. dit Durell, S. E. A., Sitters, H. P. \& Swinfen, R. 1982. Age-structure and survival of a wintering population of Oystercatchers. Bird Study 29: 83-98.

Gunnarsson, T. G. 2009. Numbers of Eurasian Golden Plovers Pluvialis apricaria in Iceland in late October 2008. Wader Study Group Bull. 116: 157-159.

Gunnarsson, T. G. \& Tómasson, G. 2011. Flexibility in spring arrival of migratory birds at northern latitudes under rapid temperature changes. Bird Study 58: 1-12.

Hammer, S., Madsen, J.J., Jensen, J-K., Pedersen, K.T., Bloch, D \& Thorup, K. 2014. Færøsk trækfugleatlas:The Faroese bird migration atlas. Fróđskapur-Faroe University Press, Tórshavn.

Hegemann, A., Marra, P. P. \& Tieleman, B. I. 2015. Causes and Consequences of Partial Migration in a Passerine Bird. Am. Nat. 186: 531-546.

IINH. 2017. Vetrarfuglatalningar - Niðurstöđur [Online]. Náttúrufræđistofnun Íslands. Available: http://www.ni.is/media/vetrarfuglar/vet16/2016T0.htm [Accessed 15.09.2017].

Ingólfsson, A. 2006. The intertidal seashore of Iceland and its animal communities. The Zoology of Iceland 8: 85.

Jónsson, J. E., Gardarsson, A., Gill, J. A., Petersen, A. \& Gunnarsson, T. G. 2009. Seasonal weather effects on the common eider, a subarctic capital breeder, in Iceland over 55 years. Climate Research 38: 237-248.

Jónsson, J. E., Gardarsson, A., Gill, J. A., Pétursdóttir, U. K., Petersen, A. \& Gunnarsson, T. G. 2013. Relationships between Long-Term Demography and Weather in a Sub-Arctic Population of Common Eider. PLOS ONE 8: e67093.

Lok, T., Overdijk, O. \& Piersma, T. 2015. The cost of migration: spoonbills suffer higher mortality during trans-Saharan spring migrations only. Biol. Lett. 11.

Newton, I. 2010. Bird migration. Collins, London.

Newton, I. \& Dale, L. 1996. Relationship between Migration and Latitude Among West European Birds. J. Anim. Ecol. 65: 137-146.

Palacín, C., Alonso, J. C., Alonso, J. A., Magaña, M. \& Martín, C. A. 2011. Cultural transmission and flexibility of partial migration patterns in a long-lived bird, the great bustard Otis tarda. J. Avian Biol. 42: 301-308. 
Skarphéđinsson, K. H., Katrínardóttir, B., Guðmundsson, G. A. \& Auhage, S. 2016. Mikilvæg fuglasvæđi á Íslandi. Náttúrufræđistofnun Íslands. Available: http://utgafa.ni.is/fjolrit/Fjolrit_55.pdf [Accessed 15.09.2017].

Wernham, C. 2002. The migration atlas: movements of the birds of Britain and Ireland. T. \& A.D. Poyser, London.

Wilson, J. R. \& Morrison, R. I. G. 1981. Primary Moult in Oystercatchers in Iceland. Ornis Scand. 12: 211-215.

8 
1 Appendix 1. Detailed results of a census of Oystercatchers (Oy) Haematopus ostralegus,

2 wintering in Iceland and of other waders encountered during the survey: Purple sandpiper

3 (PS) Calidris maritima, Redshank (RS) Tringa totanus, Turnstone (TS) Arenaria interpres and

4 Curlew $(\mathrm{Cu})$ Numenius arquata. Survey: $\mathrm{G}=$ ground survey, $\mathrm{A}=$ aerial survey. Areas which are

5 not covered by Christmas counts are in bold.

\begin{tabular}{|c|c|c|c|c|c|c|c|c|}
\hline Region & Area & Coordinates & Survey & Oy & PS & RS & TS & $\mathbf{C u}$ \\
\hline E Ice & Norðfjörður & $65^{\circ} 08^{\prime},-13^{\circ} 41^{\prime}$ & $\mathrm{G}$ & - & 13 & - & - & - \\
\hline E Ice & Reyðarfjörður & $65^{\circ} 01^{\prime},-13^{\circ} 55^{\prime}$ & G & - & 16 & 7 & 2 & - \\
\hline E Ice & Fáskrúðsfjörður & $64^{\circ} 55^{\prime},-13^{\circ} 58^{\prime}$ & G & - & - & 9 & - & - \\
\hline E Ice & Berufjörður & $64^{\circ} 45^{\prime},-14^{\circ} 26^{\prime}$ & G & 14 & 15 & 10 & - & - \\
\hline E Ice & Hamarsfjörður & $64^{\circ} 39^{\prime},-14^{\circ} 25^{\prime}$ & $\mathrm{G}$ & 128 & 100 & 4 & - & 9 \\
\hline SE Ice & Horna-/Skarðsfjörður & $64^{\circ} 16^{\prime},-15^{\circ} 08^{\prime}$ & $\mathrm{G}$ & 437 & 606 & 5 & 4 & 25 \\
\hline SW Ice & Reykjanes & $63^{\circ} 55^{\prime},-22^{\circ} 20^{\prime}$ & $\mathrm{G}$ & 100 & 50 & 15 & 12 & 12 \\
\hline SW Ice & Vatnsleysuströnd & $64^{\circ} 01^{\prime},-22^{\circ} 13^{\prime}$ & G & 1 & 21 & - & 40 & - \\
\hline SW Ice & Hafnafjörður-Álftanes & $64^{\circ} 05^{\prime},-21^{\circ} 58^{\prime}$ & $\mathrm{G}$ & 56 & 2 & 2 & - & - \\
\hline SW Ice & Reykjavík-Garðabær & $64^{\circ} 08^{\prime},-21^{\circ} 58^{\prime}$ & G & 340 & 284 & 33 & 5 & - \\
\hline SW Ice & Kjalarnes & $64^{\circ} 14^{\prime},-21^{\circ} 49^{\prime}$ & G & 102 & 27 & - & 1 & - \\
\hline SW Ice & Hvalfjörður & $64^{\circ} 22^{\prime},-21^{\circ} 25^{\prime}$ & G & 505 & - & - & 3 & - \\
\hline SW Ice & Grunnafjörður & $64^{\circ} 22^{\prime},-21^{\circ} 56^{\prime}$ & $\mathrm{G}$ & 1229 & 30 & - & - & 23 \\
\hline SW Ice & Borgarfjörður & $64^{\circ} 32^{\prime},-21^{\circ} 56^{\prime}$ & $\mathrm{G}$ & 866 & - & - & - & - \\
\hline W Ice & Álftanesvogur & $64^{\circ} 28^{\prime},-22^{\circ} 11^{\prime}$ & A & 40 & - & - & - & - \\
\hline W Ice & Straumfjörður & $64^{\circ} 28^{\prime},-22^{\circ} 13^{\prime}$ & G & 90 & 540 & - & 1 & - \\
\hline W Ice & Álftarós & $64^{\circ} 33^{\prime},-22^{\circ} 16^{\prime}$ & $\mathrm{A}$ & 340 & 28 & 3 & - & - \\
\hline W Ice & Traðir-Helgrindur & $64^{\circ} 35^{\prime},-22^{\circ} 21^{\prime}$ & G & 42 & - & - & - & - \\
\hline W Ice & Akrarós & $64^{\circ} 39^{\prime},-22^{\circ} 21^{\prime}$ & $\mathrm{G}$ & 1170 & 660 & - & 2 & - \\
\hline W Ice & Kaldárós & $64^{\circ} 44^{\prime},-22^{\circ} 21^{\prime}$ & G & 870 & - & - & - & - \\
\hline W Ice & Stórahraunsnes & $64^{\circ} 47^{\prime},-22^{\circ} 26^{\prime}$ & G & 32 & - & - & - & - \\
\hline W Ice & Syðra-Skógarnes & $64^{\circ} 46^{\prime},-22^{\circ} 34^{\prime}$ & G & 1298 & 280 & - & 2 & - \\
\hline W Ice & Snæfellsnes North & $64^{\circ} 58^{\prime},-23^{\circ} 04^{\prime}$ & $\mathrm{G}$ & 1576 & 573 & 7 & 23 & - \\
\hline W Ice & Hvammsfjörður & $65^{\circ} 05^{\prime},-21^{\circ} 47^{\prime}$ & A & 420 & 107 & - & - & - \\
\hline NW Ice & Breiðafjörður North & $65^{\circ} 35^{\prime},-22^{\circ} 30^{\prime}$ & $\mathrm{A} / \mathrm{G}$ & 1012 & 548 & - & - & - \\
\hline NW Ice & Breiðafjörður, Islands & $65^{\circ} 23^{\prime},-22^{\circ} 46^{\prime}$ & A & 389 & 1135 & - & 1 & - \\
\hline NW Ice & Patreksfjörður & $65^{\circ} 33^{\prime},-23^{\circ} 56^{\prime}$ & G & - & 60 & - & - & - \\
\hline NW Ice & Tálknafjörður & $65^{\circ} 37^{\prime},-23^{\circ} 49^{\prime}$ & G & - & 46 & - & - & - \\
\hline NW Ice & Dýrafjörður & $65^{\circ} 52^{\prime},-23^{\circ} 26^{\prime}$ & G & 26 & 60 & - & - & - \\
\hline NW Ice & Skutulsfjörður & $66^{\circ} 03^{\prime},-23^{\circ} 09^{\prime}$ & G & 34 & - & 10 & - & - \\
\hline NW Ice & Steingrímsfjörður & $65^{\circ} 41^{\prime},-21^{\circ} 41^{\prime}$ & $\mathrm{G}$ & 2 & 517 & - & - & - \\
\hline NW Ice & Kollafjörður & $65^{\circ} 33^{\prime},-21^{\circ} 28^{\prime}$ & G & 2 & 98 & - & - & - \\
\hline NW Ice & Bitrufjörður & $65^{\circ} 27^{\prime},-21^{\circ} 24^{\prime}$ & G & - & 121 & - & - & - \\
\hline NW Ice & Hrútafjörður & $65^{\circ} 14^{\prime},-21^{\circ} 05^{\prime}$ & G & 20 & 10 & - & - & - \\
\hline \multirow[t]{2}{*}{ N Ice } & Kópasker & $66^{\circ} 18^{\prime},-16^{\circ} 26^{\prime}$ & $\mathrm{G}$ & - & 37 & - & - & - \\
\hline & Total & & & 11141 & 5984 & 105 & 96 & 69 \\
\hline
\end{tabular}


1 Table 1. Number of Icelandic wintering Oystercatchers recorded in different regions during the 2017

2 census (28 Jan - 3 Feb). See Figure 1 for regions.

$\begin{array}{lrr}\text { Region } & \text { Number } & \text { \% of total } \\ \text { SW } & 3,199 & 28,7 \\ \text { W } & 5,878 & 52.8 \\ \text { NW } & 1,485 & 13.3 \\ \text { N } & 0 & 0 \\ \text { E } & 142 & 1.3 \\ \text { SE } & 437 & 3.9 \\ \text { S } & 0 & 0 \\ \text { total } & \mathbf{1 1 , 1 4 1} & \mathbf{1 0 0}\end{array}$


1 Table 2. Estimated percent of resident Oystercatchers in relation to breeding latitude ordered from

2 north to south and mean January temperatures (http://www.yr.no) across the range.

$\begin{array}{llcccl}\text { Country } & \text { Place } & \mathbf{N}^{\circ} & \begin{array}{c}\text { Mean temp in } \\ \text { January }\left(\mathbf{C}^{\circ}\right)\end{array} & \begin{array}{c}\text { Estimated } \\ \text { residents }\end{array} & \begin{array}{l}\text { Source } \\ \text { North Norway }\end{array} \\ \text { Troms } \varnothing & 69.6 & -4.4 & \text { None } & \text { (Bakken et al. 2003) } \\ \text { Iceland } & \text { Reykjavík } & 64.4 & -0.6 & \sim 30 \% & \text { (Skarphéðinsson et al. 2016) } \\ \text { Mid Norway } & \text { Verdal } & 63.8 & -4.5 & \sim \text { none } & \text { (Bakken et al. 2003) } \\ \text { Faroe islands } & \text { Tórshavn } & 62.0 & 3.4 & \sim \text { none } & \text { (Hammer } \text { et al 2014) } \\ \text { South Norway } & \text { Kristiansand } & 58.2 & -1.7 & \sim \text { none } & \text { (Bakken et al. 2003) } \\ \text { Sweden } & \text { Gothenborg } & 57.7 & -0.9 & \sim \text { none } & \text { (Duriez et al. 2012) } \\ \text { Denmark } & \text { Esbjerg } & 55.4 & 0.8 & \text { Mostly residents } & \text { (Duriez et al. 2012) } \\ \text { Germany } & \text { Schleswig-Holstein } & 54.5 & 0.9 & \text { Mostly residents } & \text { (Duriez et al. 2012) } \\ \text { Netherlands } & \text { Texel } & 53.0 & 3.2 & \text { Mostly residents } & \text { (Duriez et al. 2012) } \\ \text { Britain } & \text { The Wash } & 52.9 & 3.6 & \text { Mostly residents } & \text { (Wernham 2002) }\end{array}$


1 Figure 1. Map of Iceland showing regions and names with numbers of wintering Oystercatchers

2 shown as ranges recorded at each location during this survey.

3

4 Figure 2. Total number of wintering Oystercatchers counted in Iceland during the Christmas

5 counts since 2002 (black bars) and in the present survey in 2017 (striped bar). 